\title{
The Proliferation of the Short Subject
}

\author{
By Gerald Pratley
}

Fall 1997 Issue of KINEMA

\section{The Proliferation of the Short Subject (Toronto International Short Film Festival)}

Short films -- we hear so much about them; but what is a short film, or video, these days, and where do they find their audience? In the beginning everything shot was short -- one minute long because that was all the cameras of the time could accommodate. When this technical difficulty was overcome a short became the length of one reel running ten minutes. When projectors were made to take longer reels when sound came in two tens were joined together and a short became twenty minutes. The running time of most silent films was seldom given in hours and minutes. An hour film would be six reels -- of ten minutes each, but being projected by hand, as all silent films were, they could run a bit shorter or longer, depending on how quickly or slowly the projectionist turned his machine.

Keystone Cops and their companion pictures of that era were usually ten minutes. Later, during the heyday of the studios when they owned their own circuits, all accompanying newsreels, cartoons, comedy shorts, sports commentaries, travelogues, were "one-reelers" although not always ten minutes in length (cartoons were usually between five and eight). The standard studio designation of what is a short film moved from being one reel, up to three reels, and finally to any film running up to 59 minutes. But these days, when so much of what was once considered standard practice is often changed to satisfy the whims of individuals in charge of events such as a festival, it seems that anything qualifies, bringing up the question once again -what is a short?

Today, hundreds of them in all shapes, sizes, styles and subjects, pour out from production houses, television studios, and individuals working on their own, to find their way into such showcases for shorts as Yorkton, Local Heroes, Hot Docs, Montréal (to name only a few) and to support feature-length entries in major film festivals. But in cinemas they are noticeably absent except on rare special occasions -- such as an NFB short subject nominated for an Academy Award, but did not win!

The production of shorts went into a slump when cinemas stopped showing them and network television was of little help until cable and specialty channels were introduced. They needed the short to fill the spaces between the main programs, particularly the Public Service broadcasters and Pay-TV stations showing few if any commercials. But what the stations pay for shorts seldom covers the cost of making them so once again, following the flood of them at recent short festivals comes another deluge at the recently concluded Toronto International Short Film Festival, all looking for buyers.

As at Banff, the Canadian International Festival of Amateur Films, and TVO's Telefest Student Festival, the entries come in the hundreds and thousands giving pre-selection juries headaches looking at them and deciding which among them should be accepted. One can only conclude that the length their makers go to produce shorts and to send them in to festivals around the world shows a relentless desperation to get their films shown everywhere to everyone in the never ending hope of finding success by selling them to television -- there is no where else to go. In many instances a short film is at best a calling card, a credit, to prove to a prospective employer that its maker does indeed know something about producing a film. On finding employment the fortunate individual vows never again to go through the struggle to make a short. But others raise more money, somehow or the other, and after spending a year on the festival circuit settle down to make another. Others just give up and go into law, medicine or teaching! Then there are those who consider themselves artists, visual or literary, who are quite happy to live on grants enabling them to make experimental works for showing to friends in their basement -- who will be the only audiences to understand them.

Within the Toronto Short Film Festival, which received well over a thousand entries from around the world, there were four strong Canadian programs each made up of ten entries ranging over drama, comedy, documentary, animations and experimental. The best among the four groups were The Hangman's Bride (drama) by Naomi McCormack telling the true story of a woman who escaped the gallows in mid-18th century Québec by getting married; Lost in the No-Zone (experimental) by James Rae, a man's relentless search to prove that 
angels exist; Accident (comedy) by Julien Levy, a delightful chain-of-events romance; and Jules (animation) by Abigail Steinberg, a painstaking work about a reporter who meets a mysterious and elusive performer in an underground club.

But the winners among them as the Best Canadian short subjects (they should not have all been lumped together) were two exceptional and imaginative films, Twisted Sheets and Les marches de Londres (London's Markets). The first, by Christine Deacon, is a bright and lively, witty and romantic comedy of coincidences; and the second, by Mireille Dansereau, goes back 25 years to recall memories, using actual film taken at that time of her love affair -- with film and a fellow student -- while studying in London. They are never seen, and their voices blend beautifully with the shades of sadness and regret for a lost life.

It goes without saying that film is above all else a visual medium. Filmmakers in short subjects tend to forget this with the result that many of the 40-odd titles shown each day quickly fade away. But those such as Twisted Sheets and London's Markets, short as they are, remain long in memory.

\section{Author Information}

Gerald PRATLEY, OC, LLD, started his career as film critic with the CBC. In 1969, he founded the Ontario Film Institute which he directed until 1990. He has written several books and numerous articles on film, including Torn Sprockets, a history of Canadian cinema. He taught Film History in universities in Toronto and Waterloo, Canada and holds three honorary degrees from Canadian and US universities.

Gerald A. Pratley (1923-2011) was born and educated in London, England, and came to Canada in 1946. He started working in Toronto for the $\mathrm{CBC}$ as a scriptwriter. He was drawn toward working in motion pictures, and became, in 1948, the CBC's first film critic and commentator.

Gerald Pratley broadcast three programmes a week, Pratley at the Movies, The Movie Scene, Music From the Films, and others, until 1975. During this time he also became the first post-war chairman of the Toronto Film Society, chairman of the Toronto and District Film Council and co-founder of the A-G-E Film Society and correspondent for international magazines such as Films and Filming, Film In Review, Variety, Hollywood Quarterly and International Film Guide. During the 1950s he wrote for Canadian Film Weekly and Canadian Film Digest.

He became known as a speaker on all aspects of motion picture art and industry, and was invited to teach film history at the University of Toronto, York University, University of Waterloo, Seneca College and Ryerson Polytechnical University, with individual lectures being given at many other Canadian and US universities and colleges. He has served as a member of various judging panels of competitions and festivals, being one of the members of the first Canadian Film Awards in 1949.

From 1970 to 1975 he was the director of the Stratford (Ontario) International Film Festival, and from 1969 to 1976 he was Chairman of the International Jury of the Canadian Film Awards. He has attended all the world's leading festivals of film, and in particular, for 30 years, the Cannes Festival as CBC correspondent. He has written six books, The Films of Frankenheimer: Forty Years in Film; The Cinema of John Frankenheimer; The Cinema of Otto Preminger; The Cinema of David Lean; The Cinema of John Huston, and Torn Sprockets, a history of the Canadian cinema.

Gerald Pratley has served on the Advisory Boards of the film departments of Ryerson Polytechnical University and Humber College, and as a member of the programme committee of TV Ontario. In 1968 he became the founder-director of the Ontario Film Institute of the Province of Ontario, an organization which has distinguished itself in archival holdings and public service and is known since 1990 as the Cinematheque of Ontario. He taught Film History courses at the Department of Film and Photography, Ryerson Polytechnic University, Toronto and the University of Waterloo.

In 1984, Gerald Pratley was made a Member of the Order of Canada and in 2003 Officer of the Order of Canada for his service to Canada through film appreciation. He holds Honorary Degrees in Letters and Fine Arts from York and Waterloo Universities (Ont., Canada) and Bowling Green State University (Ohio, USA). 
In 2002, Gerald Pratley received a Special Genie Award from the Academy of Canadian Cinema \& Television in recognition of his lifelong dedication to the promotion and his exceptional support of Canadian cinema.

He died on 14 March 2011 in Ontario, Canada. 